\title{
ЛИТОЛОГИЯ
}

УДК 552.54:550.42

\section{Изотопия и морфология новообразованных карбонатов карбонатно-сульфатного массива Ледяная гора}

\author{
О.И. Кадебская, Т.А. Калинина, И.И. Чайковский \\ Горный институт УрО РАН, 614007, Пермь, ул. Сибирская, 78а \\ E-mail: icecave@bk.ru \\ (Статья поступила в редакичю 8 мая 2015 г.)
}

\begin{abstract}
Рассмотрены морфология, изотопный и химический состав новообразованных карбонатов в разрезе карбонатно-сульфатного массива Ледяная гора и различных микроклиматических зонах Кунгурской ледяной пещеры. Установлено, что состав новообразованных карбонатов определяется их положением в разрезе: в коре выветривания они характеризуются отсутствием примесей, а ниже по разрезу показывают значительные вариации состава, что дает основание сопоставлять их с карбонатами зоны вторичного обогащения, реализуемой на карбонатном барьере. Существенное преобладание в верхней части коры выветривания кальцита, а не менее растворимого доломита позволяет предполагать, что новообразованные минералы являются не продуктом трансформации исходного материала карбонатных пачек иренской свиты, а образуются при взаимодействии сульфатнокальциевых вод с атмосферным или биогенным углекислым газом. Изучение вторичных карбонатов из разных микроклиматических зон Кунгурской ледяной пещеры показало, что температура не влияет на состав новообразованных фаз, а определяет только их морфологию и вариации изотопного состава углерода. Ключевые слова: Пермский край, эвапориты, гипергенез, криогенез, изотопия.
\end{abstract}

DOI: $10.17072 /$ psu.geol.27.6

\section{Введение}

В карстовых массивах кроме процессов растворения и выноса материала имеет место его осаждение и накопление. Вопросы гипергенной трансформации карбонатных массивов рассмотрены в большом ряде работ $[14,15,17]$. Процессы, происходящие в карбонатно-сульфатных массивах, имеют более сложный характер и на сегодняшний день изучены недостаточно $[2,3,10]$. Для последних предпола- гаются свои особенности структурновещественного изменения [8]. Для некоторых пещер Урала было показано [4, 6, 11], что условия происходящего в настоящее время минералообразования определяются микроклиматической зональностью.

Модельным объектом для исследования явилась Ледяная гора и расположенная в ее недрах Кунгурская ледяная пещера, протянувшаяся от борта долины $\mathrm{p}$. Сылва вглубь массива на 700 м, что поз- 
волило получить материал как из вертикального разреза, так и по латерали карстующегося массива. Для изучения распределения минералов по разрезу были отобраны пробы из коры выветривания и коренных пород, вскрытых скважиной № 4443 [5]. Для выявления связи вторичной минерализации с температурными условиями были отобраны пробы из различных микроклиматических зон Кунгурской ледяной пещеры.

Минералого-петрографическое изучение проб проводилось с помощью оптического стереомикроскопа Leica MZ16 и сканирующего электронного микроскопа VEGA 3 TESCAN с системой рентгеновского энергодисперсионного микроанализа INCA Energy 350/X-max 20 (операторы Е.П. Чиркова и О.В. Коротченкова). Анализ стабильных изотопов С и О проводился в Институте геологии КНЦ УрО РАН (г. Сыктывкар) на масс-спектрометрах МИ-1309 (аналитик М.А. Кудинова) и DELTA V Advantage (аналитик И.В. Смолева), а также Геологическом институте АН Словакии на масс-спектрометре МАТ253 с прибором для автоматической подготовки карбонатов Gasbench III (рук. Р. Миловский).

\section{Характеристика карбонатного матери- ала из разреза скважины}

Разрез по скважине № 4443 с положением исследованных проб карбонатного материала показан на рис. 1. Четыре из них отобраны из коры выветривания и две - из коренного массива.

Верхняя часть разреза представлена неоген-четвертичной корой выветривания мощностью до 35-38 м, сложенной известковистой глиной с дресвянощебневым материалом. В верхней части (до глубины 14,5 м) обломки представлены тонкослоистым алевролитом и аргиллитом, а в нижней $(17,4-33,0$ м) - пелитоморфным доломитом с ячеистокавернозным строением. В интервале 14,5-17,4 м вскрывается пелитоморфный тонкослоистый известковистый доломит, залегающий под углом 25-30, являющийся, вероятно, ксенолитом елкинской пачки иренской свиты. На контакте коры выветривания и подстилающих сульфатов шалашнинской пачки иренской свиты вскрыта карстовая полость (интервал глубин 33,0-38,3 м) с глинисто-дресвяными отложениями, в составе которых присутствуют карбонатные обломки.

Проба 1 отобрана из верхней части разреза (0,3-14,5 м). Здесь новообразованный кальцит отмечен в глинистой массе и на стенках трещин, где он представлен одиночными кристаллами, сростками и сложными агрегатами, которые образованы гранями острого, промежуточного и тупого ромбоэдра. Здесь также зафиксированы ромбоэдры (в комбинации с пинакоидом) доломита. Поверхность кристаллов карбонатов разная: отмечены как гладкогранные индивиды, так и с коррозионно-регенерационной поверхностью. На поверхности карбонатов наблюдаются микровыделения пирита, барита, почки и пленки гидроксидов железа и марганца.

Проба 2. Аутигенный кальцит из ксенолита елкинской пачки отмечен в виде одиночных индивидов ромбоэдрического габитуса и их агрегатов в основной массе, a также друз и щеток на поверхности микротрещин. Индивиды характеризуются блочной поверхностью, вершины некоторых расщеплены.

Проба 3. Новообразованный кальцит в нижней части разреза (интервал глубин 17,4-33,0 м) аналогичен кальциту из верхней - здесь также отмечены одиночные индивиды ромбоэдрического габитуса и их агрегаты. Нередко кальцит, иногда в ассоциации с пинакоидами и ромбоэдрами доломита, формирует друзы и щетки на стенках трещин и поверхности обломков пелитоморфного известковистого доломита и известковистой глины. Доломит также отмечен в виде небольших (до 5070 мкм) сферул блочного строения. Грани кристаллов карбонатов осложнены ростовыми (блочность, расщепление) и коррозионными элементами. Акцессорные минералы представлены микровыделениями 
пирита и барита, ажурными пленками гидроксидов железа. На поверхности карбонатов отмечены многочисленные микровыделения и кристаллы барита (с примесью стронция до 21,95 ат.\%), реже пленки и почковидные образования гидроксидов железа и марганца.

Проба 4. Аутигенный кальцит из глинисто-дресвяных отложений карстовой полости (интервал глубин 33,0-38,3 м) отмечен в виде друз и щеток на поверхности обломков и оолитов доломита. Последний нередко перекристаллизован и представлен мелкозернистым агрегатом кристаллов ромбоэдрического габитуса. Среди акцессорных минералов этой зоны отмечен лишь барит, в составе которого обнаружена примесь стронция (до 3,08 ат. \%).

Пробы 5 и 6 отобраны из коренного массива: верхнего и нижнего доломитовых прослоев неволинской пачки.

Верхний доломитовый прослой сложен тонкослоистой до массивной пелитоморфной породой, дезинтегрированной до дресвяно-щебнисто-пелитового материала. В пределах слоя отмечены участки, где доломит представлен массивной мелкозернистой породой (проба 5), характеризующейся присутствием полостей, стенки которых инкрустированы ромбоэдрами (до 1 мм) кальцита, реже доломита. Основная масса породы сложена ромбоэдрами доломита (до 10 мкм) с небольшими реликтовыми участками исходного пелитоморфного известковистого доломита [8]. Среди карбонатов отмечены как гладкогранные индивиды, так и осложненные ростовыми (блочность, футляровидная структура), регенерационными и коррозионными элементами. На поверхности доломита встречены розетковидные агрегаты гипса, ажурные корочки флюорита, глобули гидроксидов железа и примазки гидроксидов марганца, состав которых отвечает формуле асболана:

$\left(\mathrm{Ni}_{0-0,05} \mathrm{Co}_{0,58-0,64}\right) \mathrm{Mn}_{1,34-1,42}(\mathrm{O}, \mathrm{OH})_{4} \cdot \mathrm{nH}_{2} \mathrm{O}$. Среди акцессорных минералов отмечены крупные (до 0,5 мм) индивиды целестина призматического габитуса и пластинчатые кристаллы гипса.
Нижний прослой в верхней части представлен тонкослоистым пелитоморфным известковистым доломитом, в подошве которого зафиксированы строматолитоподобные постройки (до 40-45 см). Ниже по разрезу доломит приобретает массивную текстуру и оолитовую структуру. Оолиты имеют размер 1-1,2 мм и характеризуются концентрическим строением (от 5 до 12 слоев). В качестве цемента на отдельных участках выступает пелитоморфный доломит, а на других - пойкилитовый гипс. Иногда здесь фиксируются участки, где доломит характеризуется высокой пористостью и крустификационным кальцитовым цементом (проба 6). Оолиты, практически во всех случаях пористые за счет выщелачивания известковой составляющей [8], сложены пинакоидальными индивидами, иногда футляровидного строения. Внутри и на поверхности оолитов нередко присутствуют более крупные пинакоидальные индивиды доломита, ромбоэдры кальцита, дипирамидальные кристаллы кварца, пойкилокристаллы целестина и гипса. В составе последнего зафиксированы реликты ангидрита и микровыделения флюорита и целестина. Заканчивается нижний доломитовый прослой тонко-, среднеслоистой пелитоморфной породой, отдельные прослои которой насыщены оолитами (до 0,20,5 мм) концентрического строения: пелитоморфное ядро (иногда с включениями гипса) и тонкая оболочка. В нижней части слоя отмечаются небольшие линзы, реже гнезда и отдельные желваки (до 1,5 см) мелкозернистого гипса [5].

\section{Характеристика карбонатного матери- ала из Кунгурской ледяной пещеры}

Для исследования минералообразования в пещере были отобраны 6 проб (рис. 2). Три из них взяты из глинистых отложений под органными трубами (пробы 79) в различных климатических зонах, другие - с поверхности наледи (проба 10), из периодически затапливаемых глинистых 


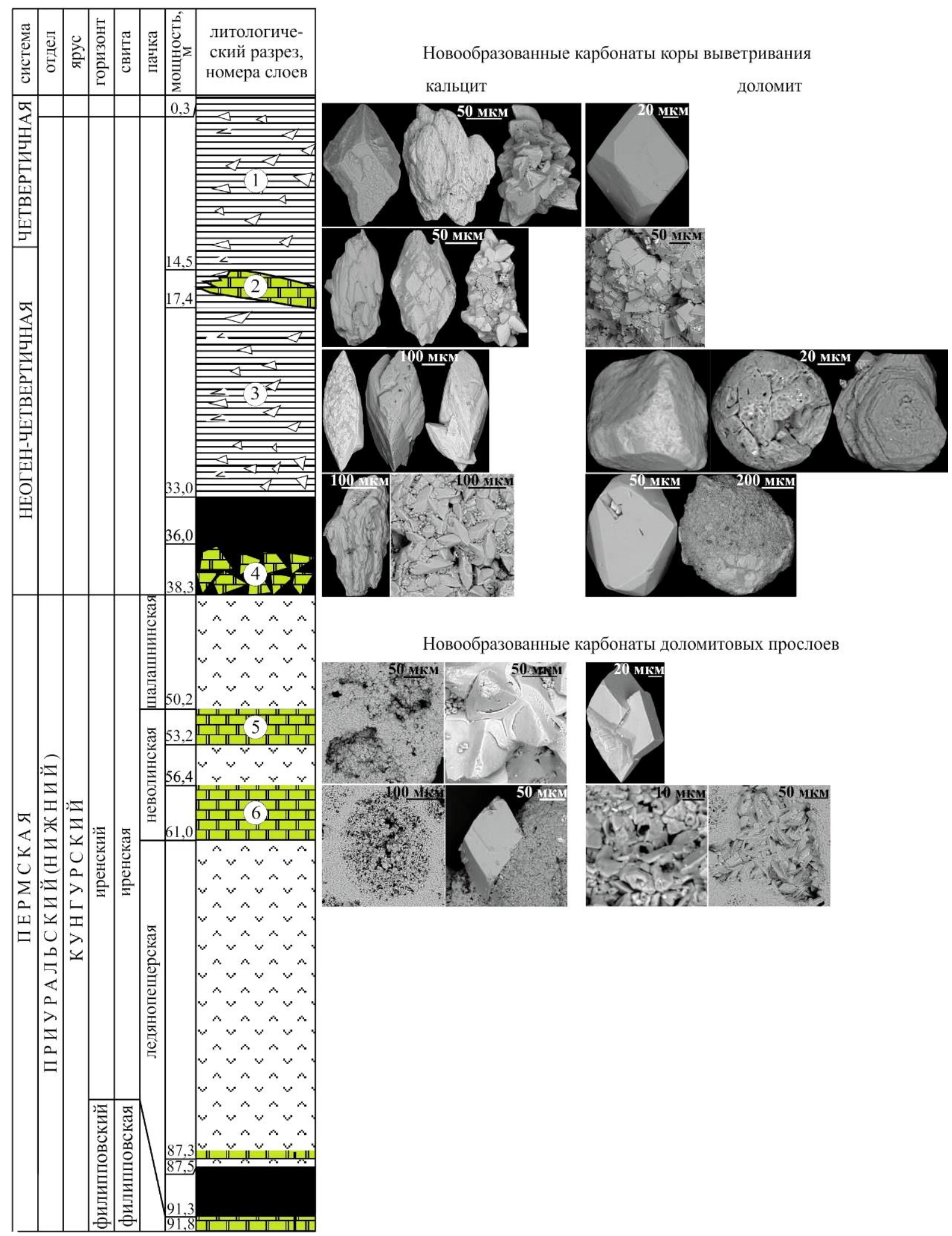

Рис. 1. Морфология новообразованных карбонатов в разрезе «Ледяная гора» (по скв. № 4443)

отложений (проба 11) и с поверхности подземного озера (проба 12).
Пробы 7-9. Материал отбирался в проходе Полярный-Данте (холодная зона), в проходе Крестовый-Руины (переходная 
зона), в гроте Эфирный (теплая зона) [4]. Отложения осыпей под устьями органных труб представлены глинистым материалом с обломками сульфатных и карбонатных пород из ледянопещерской и неволинской пачек. Изучение новообразованных фаз показало, что они представлены кальцитом и очень редко доломитом. Для кальцита характерен близкий набор морфологических типов кристаллов. Это ромбоэдрические (нормальные) кристаллы, относительно непрозрачные кремовые, более острые бесцветно-желтоватые и острые бесцветные. В холодной зоне количество новообразованных карбонатов минимально: в основном присутствуют единичные индивиды с расщепленной поверхностью. В осыпи теплой зоны кроме отдельных кристаллов и сростков отмечаются также более сложные конкрециевидные агрегаты и корочки, а в переходной - брекчиевидные агрегаты с новообразованным кальцитовым цементом. В осыпи переходной зоны зафиксированы

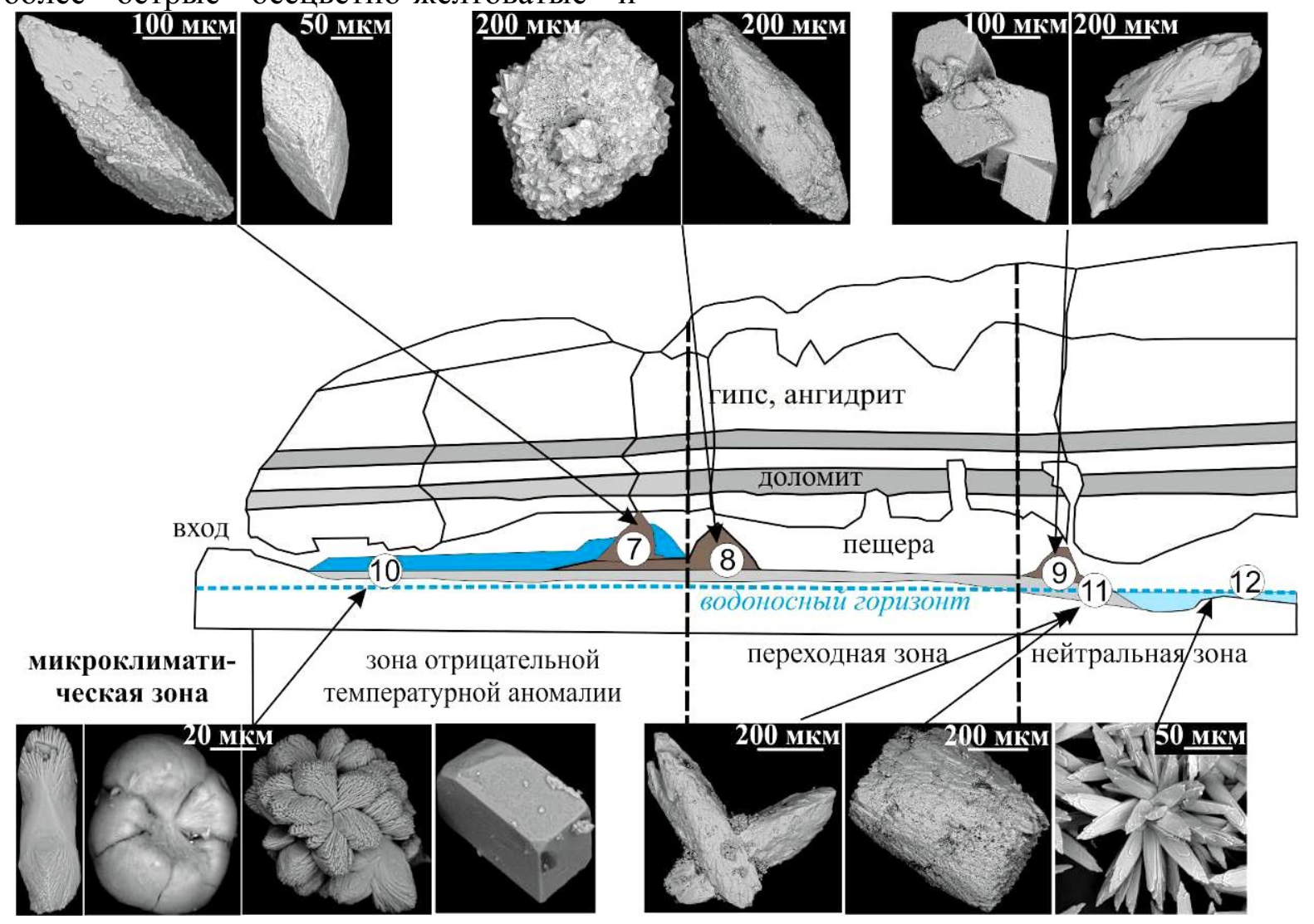

Рис. 2. Морфология новообразованных карбонатов из льда, провально-осыпных конусов и озер в различных микроклиматических зонах Кунгурской Ледяной пещеры

отдельные индивиды кальцита с регенерированной поверхностью и футляровидный доломит, что может говорить о наибольшей активности проявившихся здесь минералообразующих процессов.

Проба 10. Специфическим образованием холодной зоны Кунгурской ледяной пещеры является так называемая криогенная мука, сложенная микрокристаллами (20-60 мкм), которые формируются при вымораживании поступающих в пещеру сульфатно-кальциевых вод [1]. Кристаллизация криогенных минералов происходит в зоне отрицательной температурной аномалии в тонкой пленке воды в теплое время года, а накопление «муки» - при высвобождении из льда при его испарении в зимний период. «Мука» в основном представлена кристаллами гипса (95-97 об.\%), на кальцит, доломит и целестин приходится не более 3-5 об.\%. Кальцит представлен в основном расщепленными 
ромбоэдрами и сферолитами, а доломит кристаллами, образованными гранями тупого ромбоэдра и пинакоида.

Проба 11 отобрана в проходе между гротами Центральный и Колизей (теплая зона) из пещерного сухого грунта существенно глинистого состава (песок - 5 об.\%, дресва - 5 об.\%), который в периоды максимальных паводков затапливается. Кроме обломков гипса, доломита и аргиллита здесь зафиксированы стяжения гидроксидов марганца и кристаллы кальцита. Последние имеют бочонковидную форму и образованы гранями острого ромбоэдра и пинакоида. Кальцит также отмечен в виде корочек (головки кристаллов ориентированы внутрь) на обломках гипса и отдельных кристаллов и их сростков на корродированной поверхности реликтового гипса.

Проба 12. Кальцит был зафиксирован и на поверхности озера в гроте Близнецы (теплая зона), где он слагает плавающие пленки (raft - по [16]). Он представлен друзовидным агрегатом острых ромбоэдрических кристаллов кальцита, ориентированных вершинами вниз. Отмечено, что более крупные из них приурочены к краевым частям минеральных корок. Изредка на наружной стороне минеральных пленок в гнездах между кристаллами кальцита отмечаются целестин, доломит, гипс и галит $[4,12]$. Формирование агрегатов на поверхности озер свидетельствует о том, что пересыщение и минералообразование происходит только в поверхностном слое воды при испарении.

\section{Химический и изотопный состав ново- образованных карбонатов}

Химический анализ новообразованных карбонатов (и кальцита, и доломита) коры выветривания (рис. 3, в) показал, что их состав отвечает теоретической формуле. Незначительная примесь магния (до 2,01 ат. \%) и железа (до 1,72 ат. \%) отмечена лишь во вторичном кальците из первой пробы. В отличие от них новообразованные карбонаты из глинисто-дресвяных отложений карстовой полости (проба 4) показывают вариацию состава (рис. 3, б). Так содержание магния и железа в кальците достигает 11,68 и 1,02 ат. \% соответственно, а кальция и железа в доломите 43,15-63,12 и 1,05 ат. \%. Вторичные карбонаты неволинской пачки (пробы 5 и 6) по составу могут быть разделены на три группы (рис. 3, 2): существенно доломитовые, кальцитовые (в том числе высокомагнезиальные) и сидеритовые (сидеритдоломитовые и сидерит-анкеритовые).

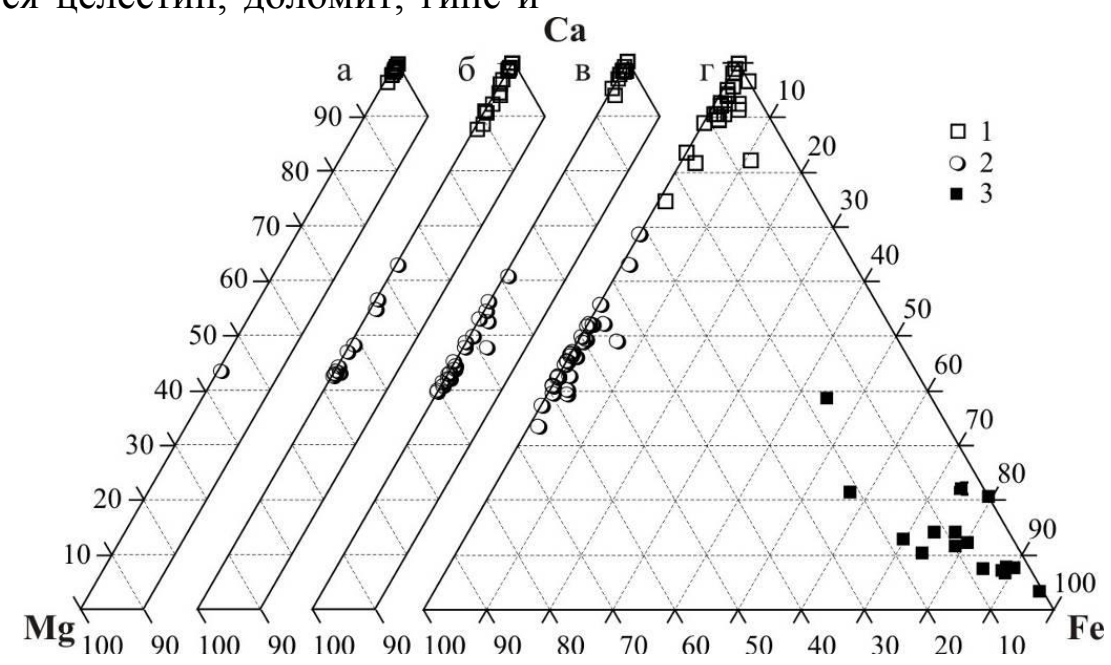

Рис. 3. Соотношение $\mathrm{Mg}-\mathrm{Ca}-\mathrm{Fe}$ в карбонатах из аккумуляциионных конусов, криогенной муки и кальичтовых озерных пленок (а), карстовой полости в шалашнинской пачке (б), коры выветривания (в) и прослоев оолитового доломита неволинской пачки (2) (ат. \%): 1 - существенно кальцитовые; 2 -доломитовые; 3 -сидеритовые 
Локальный химический анализ карбонатов из различных климатических зон Кунгурской пещеры показал незначительное количество примесей (рис. 3, $a$ ).

Анализ незатронутых процессами гипергенеза известковистых доломитов иренской и филипповской свит показал, что изотопный состав их кислорода отличается от современных и более древних эвапоритов и находится в соответствии с глобальной тенденцией утяжеления от докембрия до четвертичного периода. Исследованные доломиты по изотопному
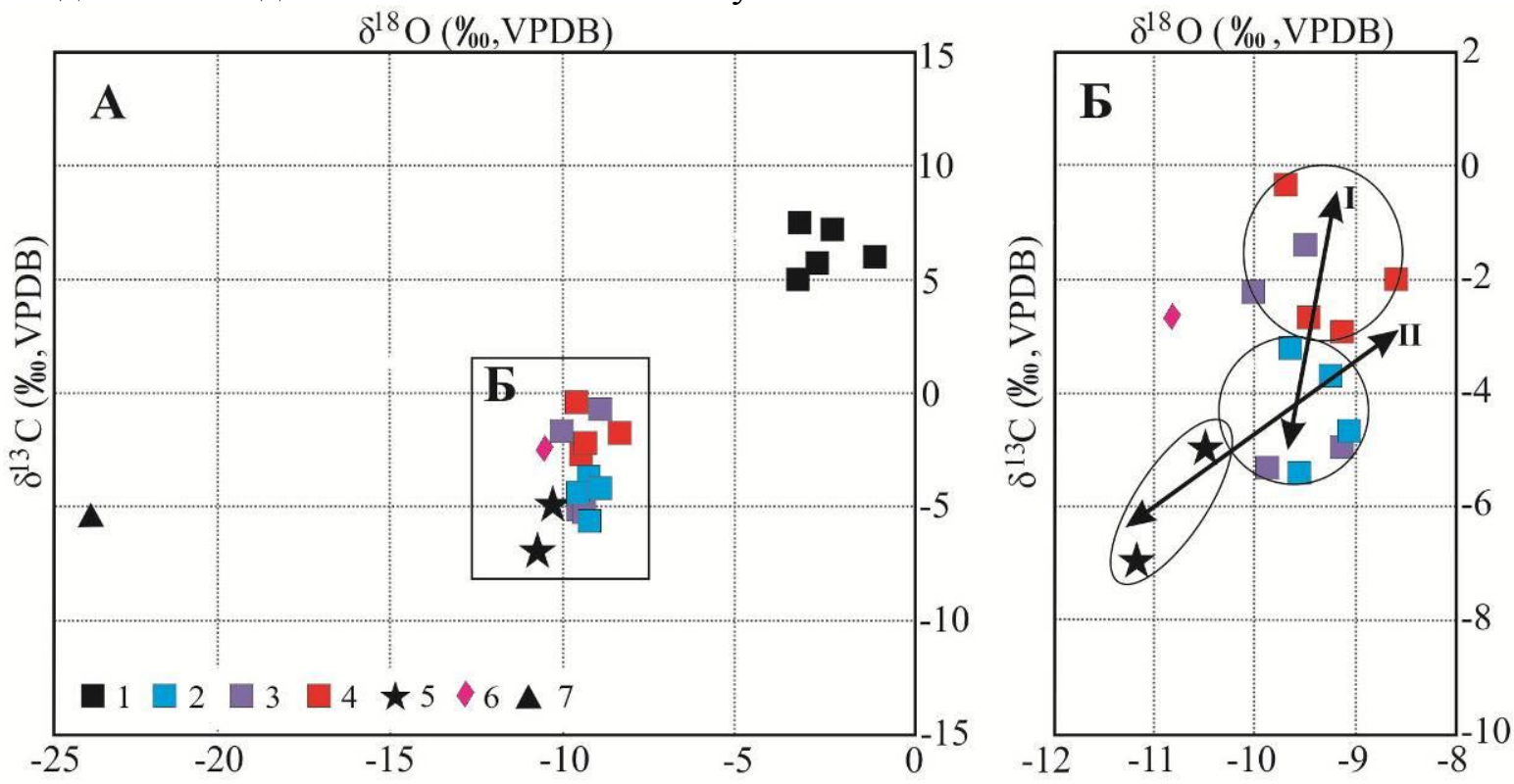

Рис. 4. Изотопный состав первично-осадочных и вторичных карбонатов Ледяной горы: 1 первично-осадочные известковистые доломиты кунгурского яруса нижней перми [7]; 2-4 новообразованный кальиит из осыпей Кунгурской ледяной пещеры (зоны: 2 - холодная; 3 - переходная; 4 - теплая); 5 - кальциит из коры выветривания [7]; 6 - кальцитовая пленка с поверхности озера; 7 - карбонат из криогенной муки грота Полярный. Стрелочками показаны вариации изотопного состава карбонатов, связанные с микроклиматической зональностью пещеры (I) и положением в разрезе (II)

кономерность: $\delta^{13} \mathrm{C}$ изменяется от $-0,5$ до $7,7 \%$, а $\delta^{18} \mathrm{O}--8,7 \div-10,4 \%$. Выявленные признаки позволяют предполагать, что кристаллизация вторичного кальцита в пещере и коре выветривания происходит одинаково. Питающим раствором являются инфильтрационные изотопно-легкие (атмогенные) воды, проходящие через почвы, содержащие органическое вещество и обогащенные ${ }^{12} \mathrm{C}$ по сравнению с первично-осадочной породой. Утяжеление изотопного состава кислорода карбо- натов из пещерных отложений по сравнению с карбонатами коры выветривания может свидетельствовать о происходящем при инфильтрации атмосферных вод фракционировании.

Анализ изотопного состава карбонатов из осыпей различных микроклиматических зон Кунгурской ледяной пещеры позволил установить, что в теплой зоне $\delta^{13} \mathrm{C}$ изменяется от $-0,5$ до $-3,0 \%$, а в холодной - от 3,3 до $-5,1 \%$. Изотопный состав кальцита в переходной зоне близок к 
карбонатам как теплой, так и холодной 3он.

Кальцитовые пленки с поверхности озер в теплой зоне сопоставимы

$\left(\delta^{13} \mathrm{C}=-2,8 \%\right.$, $\delta^{18} \mathrm{O}=-10,8 \%$ ) с обычными натечными образованиями пещер [18], связанных с разложением гидрокарбоната и испарением $\mathrm{CO}_{2}$.

Состав криогенного кальцита $\left(\delta^{13} \mathrm{C}=\right.$ $5,5 \%$, $\left.\delta^{18} \mathrm{O}=-23,7\right)$ из холодной зоны Кунгурской ледяной пещеры резко отличается от состава кальцита из осыпей и коры выветривания. Исследование процессов карбонатного минералообразования в условиях криогенеза позволило выявить два тренда фракционирования [18]. Первый характеризуется ростом содержания ${ }^{13} \mathrm{C}$ при почти постоянном значении $\delta^{18} \mathrm{O}$ и реализуется при быстрой (шоковой) кристаллизации и фракционировании подвижного ${ }^{12} \mathrm{C}$ в углекислый газ. Здесь главным фактором является кинетический, связанный с быстрым удалением $\mathrm{CO}_{2}$ и неравновесным испарением воды. Замораживание происходит настолько быстро, что фракционирование изотопов кислорода между водой и льдом не происходит.

Второй тренд определяется невозможностью дегазации $\mathrm{CO}_{2}$, если на поверхности водоема существует ледяная корка. В кристаллической структуре льда происходит фиксация тяжелого изотопа кислорода ${ }^{18} \mathrm{O}$, а в остаточных растворах, из которых происходит кристаллизация карбонатов, остается изотопно-легкий кислород [18]. Обогащенность карбонатной муки легким изотопом может быть связана с медленным замерзанием растворов внутри льда. Однако схожее изотопное диспропорционирование может быть также результатом массовой кристаллизации из растворов гипса, связывающего тяжелый изотоп ${ }^{18} \mathrm{O}$.

\section{Заключение}

Изучение структурно-вещественного строения карбонатов в разрезе карбонатно-сульфатного массива Ледяная гора показало, что в процессе гипергенеза они испытывают структурно-вещественные изменения. В результате взаимодействия первично-осадочных известковистых доломитов неволинской пачки с насыщенными сульфат-ионом инфильтрационными водами происходят выщелачивание известковой составляющей, перекристаллизация доломита и переотложение элементов, находившихся ранее в виде изоморфной примеси и собственных минеральных фаз (сидерит, целестин, барит, гидроксиды железа и марганца и др.) [8]. Присутствие минералов железа и марганца с различной степенью окисления (карбонаты и гидроксиды) свидетельствует о неравновесности условий, в которых происходило изменение исходных пород.

Химический анализ новообразованных карбонатов позволил показать, что их состав определяется положением в разрезе. Так, вторичные карбонаты из коры выветривания, характеризующейся активным проявлением процессов выщелачивания, не содержат примесей. Карбонаты из нижележащей карстовой полости в кровле шалашнинской пачки и доломитовых прослоев неволинской пачки отличаются значительными вариациями состава $(\mathrm{Ca}, \mathrm{Mg}$, $\mathrm{Fe}$ ), что дает основание сопоставлять их с зоной вторичного обогащения, реализуемой на карбонатном барьере. Существенное преобладание в верхней части коры выветривания более легкорастворимого кальцита, а не доломита, как в корах выветривания Казаковской горы [13] и Шубинского месторождения [9], позволяет предполагать, что новообразованные минералы являются не продуктом трансформации исходного материала карбонатных пачек иренской свиты, а образуются при взаимодействии сульфатно-кальциевых вод с атмосферным или биогенным углекислым газом. О реальности такого механизма может свидетельствовать облегченный состав углерода.

Незначительное количество примесей в карбонатах из разных микроклиматических зон Кунгурской ледяной пещеры может говорить о несущественном влиянии температуры на состав новообразо- 
ванных фаз. Микроклимат определяет только активность процессов минералообразования, проявленных в морфологическом разнообразии образующихся кристаллов и агрегатов, а также вариации изотопного состава $\delta^{13} \mathrm{C}$ (в теплой зоне - $0,5 \div-3,0 \%$, а в холодной $-3,3 \div-5,1 \%$ ).

Работа выполнена в рамках программы УрО РАН № 15-18-5-16 «Экстремальные (галогенные и криогенные) прочессы в геологической истории Урала: минеральные и геохимические индикаторы»».

\section{Библиографический список}

1. Андрейчук В.Н., Галускин Е. Криогенные минеральные образования Кунгурской ледяной пещеры // Пещеры. Пермь, 2001. С. 108-116.

2. Горбунова K.A. Гидратация ангидрита и сопутствующие ей явления // Карст и гидрогеология Предуралья. Свердловск: УНЦ AH CCCP, 1979. C. 35-41.

3. Горбунова К.А., Максимович Е.Г. Эпигенетические деформации в гипсо-ангидритовых толщах // Гидрогеология и карстоведение. Пермь, 1975. Вып. 7. С. 60-65.

4. Кадебская О.И. Процессы трансформации гравитационных осадков органных труб в различных микроклиматических зонах Кунгурской Ледяной пещеры // Стратегия и процессы освоения георесурсов: матер. ежегод. науч. сессии ГИ УрО РАН. Пермь, 2010. C. 6-8.

5. Кадебская О.И., Калинина Т.А. Литологический разрез Ледяной горы // Комплексное использование и охрана подземных пространств: матер. Междунар. науч.практ. конф. ГИ УрО РАН. Пермь, 2014. С. 42-49.

6. Кадебская О.И., Чайковский И.И. Экологическая минералогия Кунгурской Ледяной пещеры // Вестник Горного института УрО РАН. Горное Эхо. Пермь, 2009. № 3. C. 28-37.

7. Калинина T.A. Изотопный состав эвапоритов Пермского Прикамья и продуктов их выветривания // Виртуальные и реальные литологические модели: матер. Всерос. школы по литологии / ИГГ УрО РАН. Екатеринбург, 2014. С. 67-69.
8. Калинина T.A. Структурно-текстурная и минералогическая характеристика пород Кунгурской Ледяной пещеры и их трансформация при карстообразовании // Проблемы минералогии, петрографии и металлогении: сб. науч. ст./ Перм. гос. ун-т. Пермь, 2013. Вып. 16. С. 201-208.

9. Калинина Т.А., Чайковский И.И. Минералогия коры выветривания на Шубинском месторождении // Проблемы минералогии, петрографии и металлогении: сб. науч. ст. / Перм. гос. ун-т. Пермь, 2012. Вып. 15. С. 106-114.

10.Печеркин А.И. Геодинамика сульфатного карста. Иркутск: Изд-во Иркут. ун-та, $1986.170 \mathrm{c}$.

11. Чайковский И.И., Кадебская О.И. Минеральные образования пещеры Еранка на Северном Урале // Проблемы минералогии, петрографии и металлогении: сб. науч. ст. Пермь, 2014. Вып. 17. С. 92-107.

12. Чайковский И.И., Кадебская О.И., Калинина T.A. Минералогия пленок на поверхности водоемов Кунгурской Ледяной пещеры // Кристаллическое и твердое некристаллическое состояние минерального вещества: матер. минералог. сем. с междунар. участием. Сыктывкар, 2012. С. 346-348.

13. Чайковский И.И., Кадебская О.И., Чиркова Е.П. О гипергенной природе флюоритового оруденения Казаковской горы // Вестник недропользователя Пермского края. Природные ресурсы. Пермь, 2010. № 2 (29). C. 83-91.

14.Encyclopedia of caves and karst science / edited by John Gunn. New York, 2004. 1940 p.

15.Ford D.C., Williams P.W. Karst hydrogeology and geomorphology. Chichester: John Wiley and Sons, 2007. 565 p.

16. Hill C., Forti P. Cave minerals of the World. Huntswille, 1997. 480 p.

17.Panos $V$. Genetic features of a specific type of the karst in the centrale european climate morphogenetic area // Probl. Speleol. Res. Intern. Speleol. Confer. Praha, 1965. P. 11-23. 18.Zak K., Richter D.K., Filippi M., Zivor R., Deininger M., Mangini A., Scholz D. Coarsely crystalline cryogenic cave carbonate - a new archive to estimate the Last Glacial minimum permaforst depth in Central Europe // Climate of the Past. 2012. № 8. P. 1-17. 


\title{
Isotopy and Morphology of the Newly Formed Car- bonates of the Ledynaya Gora Carbonate-sulfate Massif
}

\author{
O. I. Kadebskaya, T.A. Kalinina, I.I. Chaykovskiy \\ Mining Institute of Ural Branch of the Russian Academy of Science. 78A \\ Sibirskaya Str., Perm 614007, Russia. E-mail: icecave@ bk.ru
}

The morphology, isotope, and chemical composition of newly formed carbonates of the Ledynaya Gora carbonate-sulfate massif in various microclimatic zones of the Kungur Ice Cave are considered. It was found that composition of newly formed carbonates is influenced by their location in the geological section. In weathering crust they are characterized by lack of impurities, but, below, they demonstrate the variation in composition. It allows associating them with the secondary enrichment zone related to a carbonate barrier. Calcite prevalence at the top of weathering crust allows assuming that newly formed minerals are not a transformation product of basic material of the carbonate member of the Irensky Suite and formed due to interaction of sulfate-calcium waters with atmospheric or biogenic carbon dioxide. Studying of newly formed carbonates from different microclimatic zones of the Kungur Ice cave showed that temperature does not affect the composition of newly formed minerals, and influences only their morphology and variations of carbon isotope composition.

Key words: Perm Region; evaporates; hyper genesis; cryogenesis; isotopy.

\section{References}

1. Andrejchuk V.N., Galuskin E. 2001. Kriogennye mineralnye obrazovaniya Kungurskoy ledyanoy peshchery [Cryogenic minerals of the Kungur Ice Cave]. In Peshchery. Perm. pp. 108-116. (in Russian)

2. Gorbunova K.A. 1979. Gidratatsiya angidrita i soputstvuyushchie ey yavleniya [Anhydrite hydration and associated phenomena]. In Karst i gidrogeologiya Preduralya. Sverdlovsk: UNTS AN SSSR. pp. 35-41. (in Russian)

3. Gorbunova K.A., Maksimovich E.G. 1975. Epigeneticheskie deformatsii $\mathrm{v}$ gipsoangidritovykh tolshchakh [Epigenetic deformation in gupsum-anhydrite massif]. In Gidrogeologiya i karstovedenie. Perm, 7: 6065. (in Russian)

4. Kadebskaya O.I. 2010. Protsessy transformatsii gravitatsionnykh osadkov organnykh trub $\mathrm{v}$ razlichnykh mikroklimaticheskikh zonakh Kungurskoy Ledyanoy peshhery [Transformation processes in organ pipe gravitional deposits from various microclimatic zones of the Kungur Ice Cave]. In Strategiya $\mathrm{i}$ protsessy osvoeniya georesursov. Perm. pp. 68. (in Russian)

5. Kadebskaya O.I., Kalinina T.A. 2014. Litologicheskiy razrez Ledyanoy gory [Lithological cross-section of the Ledyanaya Gora]. In Kompleksnoe ispolzovanie i okhrana podzemnykh prostranstv. Perm. pp. 42-49. (in Russian)

6. Kadebskaya O.I., Chaykovskiy I.I. 2009. Ekologicheskaya mineralogiya Kungurskoy Ledyanoy peshchery [Ecological mineralogy of the Kungur Ice Cave]. In Gornoe Echo: Vestnik GI UrO RAN. 3: 28-37. (in Russian)

7. Kalinina T.A. 2014. Izotopnyy sostav evaporitov Permskogo Prikamya i produktov ikh vyvetrivaniya [Isotope composition of the Perm Prikamye evaporites and products of their weathering]. In Virtualnye i realnye litologicheskie modeli. Ekaterinburg. pp. 67-69. (in Russian)

8. Kalinina T.A. 2013. Strukturno-teksturnaya i mineralogicheskaya kharakteristika porod Kungurskoy Ledyanoy peshchery i ikh transformatsiya pri karstoobrazovanii [The struc- 
tural, textural and mineralogical characteristic of the Kungur Ice Cave rocks and their transformation due to karstification]. In Problemy mineralogii, petrografii i metallogenii. Perm. 16: 201-208. (in Russian)

9. Kalinina T.A., Chaykovskiy I.I. 2012. Mineralogiya kory vyvetrivaniya na Shubinskom mestorozhdenii [Mineralogy of the weathering crust in the Shubino deposit]. In Problemy mineralogii, petrografii i metallogenii. Perm. 15: 106-114. (in Russian)

10.Pecherkin A.I. 1986. Geodinamika sulfatnogo karsta [Geodynamics of the sulphate karst]. Irkutsk: Izd. Irkut. univ. p. 170. (in Russian)

11.Chaykovskiy I.I., Kadebskaya O.I. 2014. Mineralnye obrazovaniya peshchery Yeranka na Severnom Urale [Mineral formations of the Yeranka Cave (Northern Urals)]. In Problemy mineralogii, petrografii i metallogenii. Perm. 17: 92-107. (in Russian)

12.Chaykovskiy I.I., Kadebskaya O.I., Kalinina T.A. 2012. Mineralogiya plyonok na poverkhnosti vodoemov Kungurskoy Ledyanoy peshchery [Mineral films on the surface of the Kungur Ice Cave lakes]. In Kristallicheskoe i tverdoe nekristallicheskoe sostoyanie mineralnogo veshchestva. Syktyvkar. pp. 346-348. (in Russian)
13.Chaykovskiy I.I., Kadebskaya O.I., Chirkova E.P. 2010. O gipergennoy prirode flyuoritovogo orudeneniya Kazakovskoy gory [About the hypergene nature of a fluorite mineralization of the Kazakovskaya Gora]. In Prirodnye resursy: Vestnik nedropolzovatelya Permskogo kraya. Perm. 2 (29): 83-91. (in Russian)

14.Encyclopedia of caves and karst science 2004. New York. p. 1940.

15.Ford D.C., Williams P.W. 2007. Karst hydrogeology and geomorphology. Chichester, John Wiley and Sons, p. 565.

16. Hill C., Forti P. 1997. Cave minerals of the World. Huntswille. p. 480.

17.Panos V. 1965. Genetic features of a specific type of the karst in the centrale european climate morphogenetic area. In Probl. Speleol. Res. Intern. Speleol. Conf. Praha. pp. 11-23.

18.Zak K., Richter D.K., Filippi M., Zivor R., Deininger M., Mangini A., Scholz D. 2012. Coarsely crystalline cryogenic cave carbonate - a new archive to estimate the Last Glacial minimum permafrost depth in Central Europe. In Climate of the Past, 8: 1821-1837. doi:10.5194/cp-8-1821-2012 